\title{
О.Т. КУЗЯРІН
}

Державний природознавчий музей НАН України

вул. Театральна, 18, м. Львів, 79008, Україна

kuzyarin@gmail.com

\section{НОВИЙ ЛОКАЛІТЕТ SPIRANTHES SPIRALIS (ORCHIDACEAE) В УКРАЇНI}

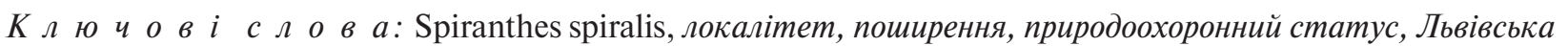
область, Україна

Spiranthes spiralis (L.) Chevall. (Orchidaceae) - таксон європейсько-середземноморського походження на східній межі ареалу з національним природоохоронним статусом «зникаючий вид» [15]. За біоморфою він належить до геофітів, за екоморфами є мезофітом, нейтрофілом, мезотрофом, геліофітом. Зважаючи на морфолого-біологічні особливості виду (відносно малі розміри, пізнє цвітіння (серпень-вересень), відсутність генеративних пагонів у несприятливі роки тощо) [1, 9-11, 24], а відтак і на складність його ідентифікації в природі, досі відсутня об'єктивна інформація щодо його поширення, зокрема на території України. Сучасні локалітети S. spiralis відомі зі Львівської, Івано-Франківської та Закарпатської областей [4, 7, 12-15]. Окрім цього, вид наводився для Тернопільської обл. [14]. В околицях Львова востаннє його збирали в 1916 р. Враховуючи гербарні ( $B P$, $K R A, K R A M, K W, L W, L W S$ ) та літературні [2-8, $12-15,18,19,22,23]$ дані, нижче наводимо перелік місцезнаходжень $\left(^{*}\right)$ S. spiralis в Україні, у т. ч., ймовірно, втрачених $(+)$.

Закарпатська обл. (три місцезнаходження, з яких одне, напевно, втрачене): Великоберезнянський р-н: * окол. с. Домашин [LWS: «... с. Домашин, пасовище на сх. схилі, 450 м н.р.м., 10.09.2006, Кваковська I.М., № 111297»]; * окол. с. Стричава $[K W: \ll \ldots$ с. Стрычава (около 700 м н.у.м.), опушка леса, поляна, 2006, Лоя В.В.»]; Хустський р-н: *(+) м. Хуст [ВР: Вагнер Л., наприкінці ХІХ ст.] [8].

Івано-Франківська обл.(чотири місцезнаходження, з яких два, ймовірно, втрачені): Косівський $p-н$ : *(+) між м. Косів і смт Кути [LWS: «Między Kosowem a Kutami, [?].07.1853, Łobarżewski H., № 25425»]; *(+) окол. с. Люча [LWS: «... Люча, гора Клифа (па polanie lasu bukowego), 01.09.1932, Пригродський М., № 25426»]; Надвірнянський $p$-н: * окол. с. Дора [LWS: «... околиці с. Яремче (Дора), біля стежки на Білий Камінь, 708 м над р.м., 22.08.2010, Борсукевич Л.М., № 116038»]; * окол. смт Яремче [4].

(c) О.Т. КУЗЯРІН, 2013
Львівська обл.(17 місцезнаходжень, із яких 14, імовірно, втрачених): м. Львів: ${ }^{(+)}$Кортумова гора [KRA: «... Kortumówka, 27.08.1874, Król Ż.»]; [KRA: «... Lwów, 02.07.1882, Ballowitz E.»]; *(+) Клепарів [LW: «Kleparów pr. Leopolim (Galiciae), 28.08.1891, Wołoszczak E., № 028802»]; *(+) Козельники [LW: «Krzaki między Malicami a Nikisiatką, [?].08.1896, № 028807»]; Бродівський р-н: *(+) окол. м. Броди [«bei Brody, Kreis Zloczów (Kloeber)» [19]]; Жидачівський $p-н$ : *(+) окол. сіл Дев'ятники та Соколівка [«Dziewietniki Wapnierka - Sokołówka, wzgórze nad Sieniawką, idąc ku Sośninie» [18]]; Жовківський $p-H:{ }^{*}(+)$ окол. с. Грибовичі [KRAM: «... Wrzosowisko (na Cossie) w Grybowiczach pod Lwowem, 27.08.1916, Miczyński K.»]; *(+) окол. с. Малехів [KRAM: «... Wrzosowisko w Małechowie pod Lwowem, 06.08.1920, Miczyński К.»]; * окол. с. Мокротин [LWS: «... околиці с. Мокротин, у ярах, 22.08.1975, Лазебна А.М., № 25427»]; Перемишлянський р-н: *(+) окол. с. Білка [7]; *(+) окол. с. Любешка [7]; Пустомитівський $p-н:{ }^{*}(+)$ окол. с. Журавники [7]; Старосамбірський $p-н$ : * окол. м. Добромиль [LWS: «К северо-западу от г. Добромиль ... Заросли можжевельника на холме, 10.09.1966, Бойко М.Ф., № 25423»]; [LW: «... м. Добромиль, пн.-зх. околиці, г. Лиса, на вершині, лука, яка випасається, 31.08.2004, Хміль Т., № 202283»]; * окол. с. Шумина [LWS: «... околиця с. Шумина, на лузі біля ялицевого лісу, 25.08.1977, Лазебна А.М., № 25428-25431»]; [ $L W:$ «... пд. окол. с. Муроване, 800 м праворуч від автотраси Добромиль - Львів, біля ялинового лісу, на пасовищній луці, 20.08.2007, Хміль Т., Сеник M., № 202282»]; [LWS: «... між селами Шумина і Муроване. Узлісся ялиново-ялицевих насаджень, на суходільній пасовищній луці, 380 м н.р.м., Пн. $49^{\circ} 30^{\prime} 27,2^{\prime \prime}$, Сх. 2255'32,9", 02.09.2008, Кузярін О.Т., Хміль Т.С., № 113278»]; Стрийський $p-н:^{*}(+)$ окол. м. Стрий [«...поблизу Стрия ... на схилах невисоких похилих горбів серед низького і рідкого різнотрав'я» [12]]; Яворівський $p-н:{ }^{*}(+)$ окол. смт Іва- 
но-Франкове [LWS: «Zalesie pod Janowem, [?].1874, Król Ż., № 25424»];*(+) окол. с. Рясне [«... na suchej łące w Strrychowaczu i w Rzęśnie, ale bardzo rzadka (w pobliżu lasku sosnowego)» [22]]; *(+) окол. с. РяснеРуське [«Im Kieferwalde bei Rzęsna Ruska, Lemberg» [23]].

Тернопільська обл. (одне, ймовірно, втрачене місцезнаходження): Ланівецький $p$-н: *(+) окол. с. Грибова [ $L W$ : «Kąclowa koło Grybowa, na pograniczu Binczarowej, ugór na glebie gliniasto kamienistej, 22.09.1922, J. Motyka, № 118826»].

Під час флористичних досліджень наприкінці літа 2012 р. поблизу м. Львова виявлено новий локалітет S. spiralis (KW, LWS: «Львівська обл., Пустомитівський р-н, пн. околиці с. Деревач. На перелозі-пасовищі поблизу ставу. 363 м над р.м., 4940'39,00" Пн. 2359'49,60" Сх., 24.08.2012, Андріїв П., Кузярін О.»). Локалітет виду зосереджений у межах вторинного рудерально-лучного угруповання, що утворилося на місці оранки (поля) зі свіжими суглинковими грунтами та близьким заляганням карбонатної материнської породи. Загальне проекційне покриття травостою на момент опису становило 92-95\%. Видова насиченість угруповання - 59 видів вищих рослин, у т. ч. 57 судинних і два мохоподібні.

В основному під'ярусі заввишки 10-15 см домінував Leontodon hispidus L. (30-50 \%). Значна представленість рудеральних і лучно-рудеральних видів (Artemisia vulgaris L., Centaurea jacea L., Cirsium arvense (L.) Scop., C. vulgare (Savi) Ten., Daucus carota L., Elytrigia repens (L.) Nevski, Hypericum perforatum L., Myosotis arvensis (L.) Hill, Odontites vulgaris Moench, Pilosella praealta (Vill. ex Gochn) F. Schultz et Sch. Bip., Scrophularia nodosa L., Sonchus arvensis L., Phalacroloma annum (L.) Dumort, Tanacetum vulgare L., Tussilago farfara L. тощо) є свідченням антропогенного походження фітоценозу. Натомість наявність у травостої діагностичних видів класу Molinio-Arrhenatheretea R. Тх. 1937 і складових синтаксонів нижчого рангу (Crepis tectorum L., Dactylis glomerata L., Festuca rubra L., Galium mollugo L., Heracleum sibiricum L., Leucanthemum vulgare Lam., Lotus corniculatus L., Medicago lupulina L., Phleum pratense L., Pimpinella saxifraga L., Plantago lanceolata L., Prunella vulgaris L., Rumex acetosa L., Trifolium pratense L., Trisetum flavescens (L.) P. Beauv., Vicia cracca L., Vicia sepium L.) підтверджує сучасне господарське використання угруповання (фрагментарне викошування та помірне випасан- ня свійськими тваринами, зокрема вівцями) й указує на напрямок сукцесії (формування мезофітної сінокісно-пасовищної луки). У слабо вираженому (менше $5 \%$ ) моховому ярусі були представлені такі евритопні види, як Barbula unguiculata Hedw. i Ceratodon purpureus (Hedw.) Brid.

Виявлена локальна популяція виду нараховувала 33 генеративні особини на площі близько $30 \mathrm{~m}^{2}$. На сьогодні основною загрозою іiі існуванню $€$ радикальна зміна або повне усунення попереднього способу та режиму використання фітоценозу, зокрема високе пасовищне та рекреаційне навантаження, розорювання тощо. Для з'ясування стратегії виду й визначення лімітуючих факторів його поширення доцільно запровадити в межах оселища популяційний моніторинг (контроль за станом популяції виду).

Таким чином, на сьогодні в Україні загалом відомо 26 місцезнаходжень S. spiralis у межах Закарпатської, Івано-Франківської, Львівської та Тернопільської областей. Із них лише сім $(29,2$ \%) можна вважати сучасними з чисельністю окремих локальних популяцій від декількох до 250 генеративних особин [14]. За фітоценотичною приуроченістю вид наводиться для трав'яних угруповань сінокісно-пасовищного використання класів Molinio-Arrhenatheretea R. Тх. 1937 (союзи: Molinion caeruleae W. Koch 1926, Bromion racemosi Tx. 1951), Festuco-Brometea Br.-Bl. et R. Tx. 1943 i NardoCallunetea Prsg. 1949 (Nardo-Galion saxatilis Prsg. 1949) [4, 14, 16, 17, 19-21]. Знахідка S. spiralis на перелозі свідчить про його пластичність і адаптаційний потенціал в умовах антропогенної трансформації рослинного покриву. Отже, можна зробити попередній висновок про те, що сучасний природоохоронний статус виду відповідає радше значенню «рідкісний», аніж «зникаючий» вид.

\section{СПИСОК ЛІТЕРАТУРИ}

1. Аверьянов Л.В. Род Spiranthes (Orchidaceae) на территории России // Ботан. журн. - 1998. - 83, № 10. - С. 104110.

2. Бойко М.П. Скрученик осінній (Spiranthes autumnalis Rich.) на Прикарпатті // Укр. ботан. журн. - 1970. - 27, № 5. - C. 664.

3. Бордзіловський E.I. Родина Зозулинцеві // Флора УРСР. - К.: Вид-во АН УРСР, 1950. - Т. 3. - С. 312405.

4. Борсукевич Л.М., Данилюк K.M. Spiranthes spiralis (L.) Chevall. (Orchidaceae) у Горганах (Українські Карпати) // Укр. ботан. журн. - 2011. - 68, № 2. - С. 205-207.

5. Визначник рослин УРСР. - Київ; Харків: Держсільгоспвидав УРСР, 1950. - 789 с. 
6. Кваковська I.M. Знахідка Spiranthes spiralis (L.) Chevall. (Orchidaceae) в Українських Карпатах // Укр. ботан. журн. - 2009. - 66, № 2. - С. 205-207.

7. Лазебна А.M. Нові місцезростання Spiranthes spiralis (L.) Chevall. (=S. autumnalis (Balb.) Rich.) // Укр. ботан. журн. - 1979. - 36, № 4. - C. 369-370.

8. Лоя B.B. Нове місцезнаходження Spiranthes spiralis (L.) Chevall. (Orchidaceae) в Україні // Укр. ботан. журн. 2009. - 66, № 2. - С. 202-204.

9. Протопопова В.В. Родина Орхідні // Визначник рослин Українських Карпат. - К.: Наук. думка, 1977. - С. 382394.

10. Протопопова В.В. Род Скрученник (Скрученик) Spiranthes Rich. // Определитель высших растений Украины. - Киев: Наук. думка, 1987. - С. 407.

11. Смольянинова Л.А. Род Скрученник - Spiranthes Rich. // Флора европейской части СССР. - Л.: Наука, 1976. T. 2. - C. 22-23.

12. Собко В.Г. Орхідеї України. - К., Наук. думка, 1989. $192 \mathrm{c}$.

13. Хміль T.C. Spiranthes spiralis (L.) Chevall. у флорі України // Мат-ли ХІІ з’їзду УБТ. - Одеса, 2006. - С. 57.

14. Хмиль Т.С., Данылик И.Н. Распространение Spiranthes spiralis (L.) Chevall. (Orchidaceae) в Украине // Вестн. Твер. гос. ун-та. - 2007. - 36, № 8. - С. 180-183.

15. Хміль T.С., Данилик I.M. Скрученик спіральний Spiranthes spiralis (L.) Chevall. // Червона книга України. Рослинний світ / За заг. ред. Я.П. Дідуха. - К.: Глобалконсалтинг, 2009. - 216 с.

16. Bernacki L. Storczyki zachodniej części polskich Beskidów // Poznań, 1999. - S. 54-55.

17. Fritz F. Goodyera und Spiranthes / hrsg. Von Horst Füller. 3, durchges. Aufl. - Wittenberg Lutherstadt: A. Ziemsen. Verlag, 1984. - $64 \mathrm{~S}$.

18. Gustawicz B. Zapiski florystyczne z powiatu bobreckiego // Spraw. Komis. Fizyogr. - 1880. - 14. - S. 13-61.

19. Herbich F. Ein Blick auf die Pflanzengeografischen Verhältnisse Galiziens // Verhandlungen zoologischbotanischen Gesellschaft in Wien. - 1864. - 14. - S. 131.

20. Kattari S. G. fil. Orchideen zwischen Chiemsee und Kaisergebirge // Die Orchidee. - 2004. - 55(6). - S. 124125.

21. Les Orchideés de France, Belgique et Luxembourg. Ouvrage collectif sous l'égide de la Société Française d'Orchidophilie. - Paris: Collection Parthénope, 1998. $416 \mathrm{p}$.

22. Trusz S. Przyczynek do flory Galicyi // Kosmos. - 1882. 7. - S. 22-27.

23. Weiss $A$. Beiträge zur Flora von Lemberg // Verhandlungen zoologisch-botanischen Gesellschaft in Wien. - 1865. 15. - S. 456.

24. Willems J.H. Les relations entre la multiplication végétative et la reproduction sexuee chez Spiranthes spiralis // L'Orchidophile. - 2004. - 35(2), N 161. - S. 139-144.

Рекомендує до друку

Надійшла 15.04.2013 p.

С.Л. Мосякін

\section{А.Т. Кузярин}

Государственный природоведческий музей НАН Украины, г. Львов

\section{НОВЫЙ ЛОКАЛИТЕТ SPIRANTHES SPIRALIS (ORCHIDACEAE) В УКРАИНЕ}

Сообщается о находке нового локалитета Spiranthes spiralis (L.) Chevall. (Orchidaceae) в августе 2012 г. на залежи вблизи г. Львова. Дана детальная характеристика нового местонахождения вида. Обобщена информация о распространении $S$. spiralis в Украине. Уточнен природоохранный статус вида.

К $ю$ ю е в ы е сл о в $а$ : Spiranthes spiralis, локалитет, распространение, природоохранный статус, Львовская область, Украина.

\section{O.T. Kuzyarin}

State Natural History Museum, National Academy of Sciences of Ukraine, Lviv

\section{A NEW LOCALITY OF SPIRANTHES SPIRALIS (ORCHIDACEAE) IN UKRAINE}

A new locality of Spiranthes spiralis (L.) Chevall. (Orchidaceae) in Ukraine is reported. It was found on the fallow field near Lviv city in August, 2012. Detailed characteristic of the new habitat of the species is given. Information on distribution of $S$. spiralis in Ukraine is summarized. The conservation status of the species is specified.

$K$ e y $\quad$ w o $\quad r d s$ : Spiranthes spiralis, locality, distribution, sozological status, Lviv Region, Ukraine. 